\title{
Pemberian Terapi Elektrokonvulsif (ECT) Terhadap Peningkatan Fungsi Kognitif Klien Gangguan Jiwa
}

\author{
Marisca Agustina \\ Dosen Tetap Program Studi Ners \\ Sekolah Tinggi Ilmu Kesehatan Indonesia Maju \\ Email : marisca_duff@yahoo.com
}

\begin{abstract}
Abstrak
Terapi elektro konvulsif merupakan suatu jenis pengobatan somatik di mana arus listrik digunakan pada otak melalui elektroda yang ditempatkan pada pelipis.. Tidak ada penilaian atau evaluasi mengenai pengaruh pemberian ECT terhadap peningkatan fungsi kognitif klien gangguan jiwa di Rumah Sakit Jiwa dr. Soeharto Heerdjan Jakarta. Penelitian bertujuan mengetahui gambaran mengenai pengaruh pemberian ECT terhadap peningkatan fungsi kognitif klien gangguan jiwa di Rumah Sakit Jiwa dr. Soeharto Heerdjan Jakarta.Penelitian ini menggunakan desain quasi eksperimen pre-post intervensi tanpa kelompok control.Sampel pada penelitian ini digunakan sebanyak 32 responden.Analisis yang dilakukan menggunakan distribusi frekuensi dan uji t dependent.Hasil penelitian menunjukkan ada pengaruh ECT terhadap fungsi kognitif klien gangguan jiwa.Hasil penelitian diharapkan menjadi masukan yang baik untuk memberikan asuhan keperawatan khususnya ditujukan untuk mempertahankan orientasi realita sesuai kapabilitasnya, dapat berkomunikasi dengan baik, dan memenuhi kebutuhan kesehariannya dengan atau tanpa bantuan.
\end{abstract}

Kata kunci :Terapi elektrokonvulsif, ECT, Kognitif

\begin{abstract}
Electroconvulsive Therapy is somatic curing that used electrical sound applied to brain through electrodes at temporal. There was no evaluation about effects of ECT on cognitive function of mental psychiatric clients at dr. Soeharto Heerdjan Jakarta. Research is aimed to describe effect of ECT on cognitive function. Research used quasi eksperimen design, pre-post intervention approaches, without control group. There were 32 respondents that participated in research as sample. Methods that used for analyzed were frequency distribution and $t$ dependent test. Result of research showed that there was an enhanced effect of ECT on cognitive function of mental psychiatric client. Hoped that nursing care services will be aware of this enhancement and achieve best quality of nursing care specially to maintain client's orientation for reality as his capability, communicate better, and meets his daily needs with his own decision without other's help.
\end{abstract}

Keywords : :Electroconvulsive Therapy, Cognitive Function 


\section{Pendahuluan}

Terapi

(Electroconvulsive Therapy $=$ ECT) merupakan suatu jenis pengobatan somatik di mana arus listrik digunakan pada otak melalui elektroda yang ditempatkan pada pelipis. ${ }^{1}$

Arus tersebut cukup untuk menimbulkan kejang grand mal, yang darinya diharapkan efek terapeutik tercapai. ECT konvensional adalah perlakuan atau prosedur ECT tanpa dilakukan anestesi, minimalisasi risiko dengan fiksasi stimulus elektrik umumnya disesuaikan pada tingkat energi minimum yang dapat menghasilkan kejang. Jumlah terapi dalam satu seri bervariasi tergantung pada respons klien. ${ }^{2}$

Umumnya terapi dilakukan 6-12 kali yang diberikan 2-3 kali seminggu. Indikasi pemberian ECT pada pasien dengan gangguan bipolar berjumlah $70 \%$; pasien dengan skizofrenia berjumlah $17 \%$. Tiga indikasi terjelas untuk ECT adalah gangguan depresif berat, episode manik dan pada beberapa kasus skizofrenia. ${ }^{3}$

Keputusan untuk menganjurkan ECT pada seorang pasien, seperti semu anjuran terapi, harus didasarkan pada pilihan terapi yang tersedia bagi pasien dan pertimbangan risiko dan manfaatnya. Alternatif utama untuk ECT biasanya farmakoterapi dan psikoterapi, tetapi ECT telah terbukti merupakan terapi yang aman dan efektif. ${ }^{3}$

Angka respons terhadap ECT adalah $80 \%$ atau lebih besar dari respons terhadap pengobatan antidepresan. ECT dapat dilakukan untuk semua orang dari sebagian besar golongan usia yang tidak ada toleransi atau gagal berespons terhadap terapi pengobatan. ${ }^{4}$

Angka mortalitas dengan ECT adalah kira-kira $0,002 \%$ per terapi dan $0,01 \%$ untuk masing-masing pasien. Angka tersebut cukup baik dibandingkan dengan risiko yang disertai dengan anestesia umum dan melahirkan anak. Kematian akibat ECT biasanya terjadi dari komplikasi kardiovaskuler dan paling mungkin terjadi pada pasien yang status jantungnya telah terganggu. ${ }^{3}$

Perawat merupakan bagian dari tim interdisiplin yang tidak hanya terlibat dalam pemberian terapi ECT, tetapi juga kolaborasi untuk mengevalusi perubahan perilaku yang diharapkan dan merekomendasikan perubahan terhadap rencana terapi klien. Dalam tim, perawat mengidentifikasi pola perilaku klien dan mengevaluasi implikasi pola tersebut berkaitan dengan terapi.

Indikasi perilaku sebagai respons terapi positif meliputi aspek perilaku dan sosialisasi, dengan perilaku peningkatan dalam aktivitas hidup sehari-hari, perubahan adaptif dalam interaksi sosial dengan orang lain; meningkatnya energi dan perubahan positif lain yaitu aspek kognitif, afektif dan psikomotor berkaitan dengan gejala target antara lain perbaikan proses pikir dan perbaikan alam perasaan. Perubahan perilaku ini dapat dicapai oleh klien dalam beberapa rangkaian/seri terapi.

Sekarang ini, diperkirakan 1 juta orang di seluruh dunia mendapat pengobatan ECT setiap tahunnya, biasanya dilakukan serangkaian 6-12 terapi diberikan 2-3 kali seminggu.

Penelitian yang dilakukan tentang pengkajian kognitif multidomain sebelum dan sesudah terapi elektrokonvulsif pada depresi psikotik: hubungan kemampuan premorbid dan perbaikan gejala, melibatkan 20 partisipan depresi psikotik (12 wanita, 8 pria) yang mendapatkan ECT, diberikan pengkajian neuropsikologis dan gejala depresif. ${ }^{5}$ Hasil penelitian menunjukkan bahwa terdapat perbaikan gejala depresif dengan pengukuran fungsi kognitif menunjukkan peningkatan. Terdapat $6(30 \%)$ partisipan menunjukkan disfungsi kognitif pra ECT (total skor $\leq 80$ ), dengan hanya 2 (10\%) menunjukkan kerusakan post ECT berkaitan dengan respons ECT yang tidak adekuat. Kesimpulan yang didapatkan bahwa penampilan kognitif tidak memburuk dan mengalami perbaikan setelah ECT pada pasien dengan depresi psikotik.

Berdasarkan data statistik, jumlah klien yang dilakukan ECT di Rumah Sakit Jiwa dr. Soeharto Heerdjan Jakarta periode bulan Oktober-Desember 2017 adalah 35 klien dengan persentasi $70 \%$ pria dan $30 \%$ wanita dengan rata-rata pelaksanaan terapi empat kali dalam satu seri ECT, yang dilakukan adalah ECT konvensional dengan fiksasi.

Kondisi yang dapat diidentifikasi di Rumah Sakit Jiwa dr. Soeharto Heerdjan Jakarta saat ini adalah tidak adanya penilaian atau evaluasi mengenai pengaruh pemberian ECT terhadap peningkatan fungsi kognitif klien gangguan jiwa di Rumah Sakit Jiwa dr. Soeharto Heerdjan Jakarta. Terkait dengan penelitian sebelumnya tentang efek ECT pada fungsi kognitif dengan menunjukkan 
perubahan yang nyata yaitu terjadi penurunan signifikan terhadap proses mengingat secara verbal. Sebagai informasi dalam memberikan asuhan keperawatan yang sesuai dengan kondisi memori yang terganggu.

Tujuan penelitian ini adalah untuk mengetahui permasalahan pengaruh pemberian ECT terhadap peningkatan fungsi kognitif klien gangguan jiwa di Rumah Sakit Jiwa dr. Soeharto Heerdjan Jakarta.

\section{Metode}

Penelitian ini menggunakan desain penelitian quasi eksperimen pre-post intervensi tanpa kelompok kontrol dengan tujuan mengungkapkan adanya pengaruh pemberian ECT pada peningkatan fungsi kognitif pada klien gangguan jiwa. ${ }^{6}$ Dengan metode ini diharapkan data yang didapat lebih lengkap, lebih mendalam dan bermakna, sehingga tujuan penelitian dapat dicapai.Analisis pengaruh ECT adalah peningkatan fungsi kognitif (berpikir, memori, menilai, orientasi, persepsi dan perhatian).

Populasi pada penelitian ini adalah semua klien dengan gangguan jiwa dengan indikasi ECT yang dirawat di RS.Jiwa Soeharto Heerdjan Jakarta.Jumlah populasi pada bulan Januari-Maret 2017 adalah 32 orang.

Untuk menentukan besar sampel yang akan diambil, maka digunakan pengambilan sampel total sampling dimana peneliti telah menetapakan ciri-ciri dan karakteristik sampel yang akan diteliti. Pada penelitian ini sampel berjumlah 32 orang.

Adapun kriteria sampel yang diteliti adalah klien adalah penderita gangguan jiwa kronis, klien memiliki indikasi pemberian terapi ECT dengan diagnosa medis utama adalah depresi dengan bunuh diri, mania akut dengan hiperaktivitas, gangguan afektif dengan eksaserbasi psikosis atau skizofrenia, klien laki-laki atau perempuan berusia diatas atau sama dengan 20 tahun, klien merupakan klien rawat inap RS Jiwa Dr. Soeharto Heerdjan Jakarta, klien bersedia menjadi responden; klien dianggap inkompeten sehingga persetujuan diwakili oleh anggota keluarga klien.

Penelitian dilakukan di ruang ECT RS Jiwa Dr. Soeharto Heerdjan Jakarta, kemudian dilanjutkan ke ruang rawat inap tempat klien dirawat.Waktu penelitian dilakukan dalam periode Januari-Maret 2017.
Pengumpulan data dilakukan dengan cara sebagai berikut :

1. Pembuatan instrument. Instrumen dirancang dalam bentuk lembar observasi digunakan untuk mencatat data peningkatan fungsi kognitif sebelum dan sesudah tindakan ECT. Rincian lembar observasi adalah :

2. Data demografi klien dengan isian inisial klien, diagnosa medis, diagnosa keperawatan, jenis kelamin, usia, pekerjaan dan suku.

3. Data observasi meliputi :

a. Frekuensi dilakukan ECT konvensional adalah satu seri rangkaian dengan pencatatan nilai pre dan post pemberian ECT pada klien.

b. Fungsi kognitif pre dan post ECT didapatkan melalui observasi meliputi fungsi kognitif yang diukur menggunakan MoCA yang sudah dimodifikasi dalam versi Indonesia. Tidak dilakukan uji validitas dan reliabilitas karena MoCA merupakan instrumen yang sudah baku penggunaannya.

Penelitian ini merupakan jenis kuasi eksperimen dengan pre dan post intervensi, dimana analisisnya bertujuan menjelaskan karakteristik variabel yang diteliti dan menentukan pengaruh dengan variabelvariabel dalam penelitian, oleh karena itu analisis yang dilakukan adalah :

Analisis Univariat

Secara teknik analisis ini merupakan kegiatan meringkas kumpulan data menjadi ukuran tengah dan ukuran variasi.Selanjutnya membandingkan gambaran tersebut antar kelompok subyek sesuai tujuan yang ingin dicapai dalam analisis.

Metode analisis yang digunakan pada penelitian ini adalah quasi eksperimen. Hipotesis diuji dengan menggunakan uji t beda dua mean dependen, yaitu melihat perbedaan mean antara dua kelompok data yang dependen. $^{7}$

Cara pengujian dilakukan dengan menghitung nilai deviasi (d) selisih sampel 1 dan sampel 2 atau rata-rata deviasi dari nilai deviasi dari data.Selanjutnya dihitung standar deviasi dari deviasi (SDd).

Pengambilan keputusan digunakan cara berdasarkan nilai $\mathrm{p}<$ alpha $(0,05)$, maka terdapat perbedaan, dan bila $\mathrm{p}>\mathrm{alpha}(0,005)$ maka tidak ada perbedaan. 
Hasil

Penelitian ini dilakukan di Ruang ECT Rumah Sakit Jiwa dr. Soeharto Heerdjan Jakarta. Penelitian ini menggunakan desain penelitian quasi eksperimen pre-post intervensi tanpa kelompok kontrol dengan tujuan mengungkapkan adanya pengaruh pemberian ECT pada peningkatan fungsi kognitif pada klien gangguan jiwa.Dengan metode ini diharapkan data yang didapat lebih lengkap, lebih mendalam dan bermakna, sehingga tujuan penelitian dapat dicapai.Analisis dilakukan pada peningkatan fungsi kognitif sebelum dan sesudah tindakan dengan menggunakan instrumen MoCA.Sampel yang diperoleh dalam penelitian ini adalah 32 sampel.

\section{Analisis Univariat}

Tabel 1. Distribusi Responden Berdasarkan Variabel yang diteliti

\begin{tabular}{llcc}
\hline \multicolumn{1}{c}{ Variabel } & \multicolumn{1}{c}{ Kategori } & n & \% \\
\hline $\begin{array}{llc}\text { Diagnosis } \\
\text { Medis }\end{array}$ & $\begin{array}{l}\text { Skizofrenia } \\
\text { Paranoid }\end{array}$ & 17 & 53,1 \\
& $\begin{array}{l}\text { Skizofrenia tidak } \\
\text { tergolongkan }\end{array}$ & 15 & 46,9 \\
Diagnosis & Halusinasi & 12 & 37,5 \\
Keperawatan & Perilaku & 2 & 6,3 \\
& kekerasan & & \\
& Isolasi social & 18 & 56,3 \\
Jenis & Laki-laki & 20 & 62,5 \\
kelamin & Perempuan & 12 & 37,5 \\
& 20-30 th & 21 & 65,5 \\
Usia & $31-40$ th & 11 & 34,4 \\
& Wiraswasta & 10 & 31,3 \\
Pekerjaan & Buruh & 6 & 18,8 \\
& Tidak bekerja & 16 & 50 \\
& Jawa & 13 & 40,6
\end{tabular}

$\begin{array}{lcc}\text { Sunda } & 7 & 21,9 \\ \text { Batak } & 5 & 15,6 \\ \text { Padang } & 6 & 18,8 \\ \text { Tionghoa } & 1 & 3,1\end{array}$

Distribusi responden menurut diagnosis medis dengan klien gangguan jiwa sebagian besar adalah skizofrenia paranoid (F20.0) yaitu 17 orang $(53,1 \%)$ sedangkan skizofrenia tidak tergolongkan (F20.3) 46,9\%.

Distribusi responden menurut diagnosis keperawatan klien gangguan jiwa sebagian besar isolasi sosial yaitu 18 orang $(56,3 \%)$ sedangkan gangguan sensori persepsi: halusinasi dan perilaku kekerasan masingmasing $37,5 \%$ dan $6,3 \%$.

Distribusi responden menurut jenis kelamin sebagian besar laki-laki yaitu 20 orang $(62,5 \%)$, sedangkan perempuan $37,5 \%$.

Distribusi responden menurut usia sebagian besar berusia 20-30 tahun yaitu 21 orang $(65,6 \%)$, sedangkan usia 31-40 tahun $34,4 \%$.

Distribusi responden menurut pekerjaan gangguan jiwa sebagian besar tidak bekerja yaitu 16 orang $(50,0 \%)$, sedangkan wiraswasta dan buruh masing-masing 31,3\% dan 18,8\%.

Distribusi responden menurut suku sebagian besar Jawa yaitu 13 orang (40,6\%), sedangkan sunda, padang, batak, dan tionghoa masing-masing $21,9 \%, 18,8 \%, 15,6 \%, 3,1 \%$.

Tabel 2. Skor fungsi kognitif sebelum dan sesudah ECT

\begin{tabular}{lllcc}
\hline Variabel & & Kategori & n & \% \\
\hline Fungsi Kognitif & Kurang & 18 & 56,3 \\
Sebelum ECT & Normal & 15 & 43,8 \\
& & & 12 & 37,5 \\
Fungsi Kognitif & Kurang & & \\
Setelah ECT & Normal & 20 & 62,5 \\
& & & \\
\hline
\end{tabular}

Distribusi responden menurut skor fungsi kognitif yang dikelompokkan sebelum ECT sebagian besar kognitif kurang yaitu 18 responden $(56,3 \%)$ sedangkan dengan kognitif normal $43,8 \%$.Distribusi responden menurut 
skor fungsi kognitif yang dikelompokkan sesudah ECT sebagian besar dengan kategori normal yaitu 20 responden $(62,5 \%)$ sedangkan kategori kurang 37,5\%.

\section{Analisis Bivariat}

Tabel 3. Pengaruh ECT terhadap Peningkatan Kognitif Klien dengan Gangguan Jiwa

\begin{tabular}{llllll}
\hline Variabel & $\begin{array}{l}\text { Me } \\
\text { an }\end{array}$ & SD & SE & Pv & $n$ \\
\cline { 1 - 3 } $\begin{array}{l}\text { Peningkata } \\
\text { n Kognitif }\end{array}$ & & & & & \\
\hline Sebelum & 25,1 & 2,90 & 0,514 & 0,01 & 32 \\
ECT & 6 & 8 & & 9 & \\
Sesudah & 26,6 & 3,38 & 0,599 & & \\
ECT & 3 & 6 & & & \\
\hline
\end{tabular}

Rata-rata skor fungsi kognitif klien gangguan jiwa sebelum ECT adalah 25,16 dengan standar deviasi 2,908. Sesudah ECT didapat rata-rata skor fungsi kognitif klienadalah 26,63 dengan standar deviasi 3,386 . Terlihat nilai mean perbedaan skor antara sebelum dan sesudah adalah 1,469 dengan standar deviasi 3,350. Hasil uji statistik didapatkan 0,019 ( $\mathrm{p}<0,05)$, maka dapat disimpulkan ada perbedaan antara fungsi kognitif klien gangguan jiwa sebelum dan sesudah ECT atau ada pengaruh ECT terhadap fungsi kognitif klien gangguan jiwa.

\section{Pembahasan}

\section{Analisis Univariat}

Karakteristik responden yang pertama adalah diagnosis medis.Indikasi yang paling sering untuk ECT adalah gangguan depresif berat, episode manik, skizofrenia dan pada beberapa kasus. ${ }^{8}$

Berdasarkan sebagian besar klien gangguan jiwa yang dilakukan ECT, diagnosis medisnya adalah skizofrenia paranoid (F20.0) $(53,1 \%)$. Indikasi ECT untuk klien skizofrenia terutama pada pasien dengan gejala skizofrenia akut, gejala positif yang nyata, katatonia atau gejala afektif dianggap paling besar kemungkinannya berespons terhadap ECT. Skizofrenia paranoid dikarakteristikkan dengan adanya waham yang relatif stabil, seringkali bersifat paranoid, biasanya disertai halusinasi, terutama pendengaran, gangguan persepsi. ${ }^{9}$ Waham dan halusinasi merupakan gejala positif pada skizofrenia. ${ }^{1}$

Karakteristik lain responden adalah diagnosis keperawatan. Tampak pada tabel 5.2, bahwa klien gangguan jiwa sebagian besar mengalami isolasi sosial (56,3\%). Isolasi sosial adalah keadaan di mana individu mengalami penurunan atau bahkan sama sekali tidak mampu berinteraksi dengan orang lain di sekitarnya. ${ }^{10}$ Isolasi sosial adalah kesendirian yang dialami individu dan dirasakan dijauhi orang lain, merupakan tingkat negatif atau mengancam ${ }^{12}$. Tanda dan gejala isolasi sosial antara lain ketidaknyamanan situasi social, cepat bosan, lambat, disfungsi interaksi, nonkomunikatif, tidak ada kontak mata, ekspresi perasaan berbeda dari orang lain, kesepian, merasa ditolak oleh orang lain, tidak berarti, asyik dengan pemikirannya sendiri, iritabel, tidak sabar dengan interaksi, sulit berkonsentrasi, sedih, afek datar sampai tumpul, perilaku menyendiri, aktivitas menurun, lesu, tidur posisi janin. ${ }^{1}$ Perilaku tersebut merupakan gejala negatif dari skizofrenia, yang merupakan indikasi dilakukannya ECT ${ }^{14}$.

Pada tabel tampak bahwa sebagian besar responden berusia 20-30 tahun (65,6\%). Berdasarkan usia dari 32 responden yang dilakukan terapi aktivitas kelompok dalam penelitian ini, paling banyak berusia 20-30 tahun $(65,6 \%)$. Usia adalah masa hidup responden yang dinyatakan dalam satuan tahun dan sesuai dengan pernyataan responden. Jenis perhitungan usia dibagi menjadi tiga yatu usia kronologis merupakan perthitungan usia yang dimulai dari saat kelahiran seseorang dengan waktu perhitungan usia; usia mental adalah usia yang didapatkan dari tahap kemampuan mental seseorang; dan usia biologis adalah perthitungan usia berdasarkan kematangan biologis yang dimiliki seseorang. Menurut bahwa usia dewasa muda rentangnya adalah usia 18-25 tahun. Pada penelitian ini, penggolongan usia 20-30 tahun termasuk usia dewasa muda. Pada usia ini, tahap perkembangan sosialnya adalah tahap self sufficient dan hubungan interdependen dengan orangtua dan teman sebaya ${ }^{15}$. Ia mengembangkan self awareness bagaimana menyeimbangkan perilaku dependen dan independen serta sensitive dan menerima perasaan dan kebutuhan diri sendiri 
dan orang lain. Ketidakmampuan responden memenuhi kebutuhannya dapat menyebabkan klien melabel dirinya dengan ketidakmampuan, pesimistik yang tinggi sehingga klien dapat menggunakan mekanisme pertahanan yang maladaptif, sebagai predisposisi terjadinya gangguan jiwa. ${ }^{1}$

Distribusi responden menurut pekerjaan klien gangguan jiwa sebagian besar tidak bekerja $(50,0 \%)$. Bekerja berkaitan dengan pendapatan.Pendapatan yang sedikit menyebabkan kesulitan finansial.Hal ini menyebabkan kemiskinan dan merupakan stressor bagi kesehatan fisik dan mental. Meskipun kemiskinan merupakan faktor risiko mutlak terjadinya gangguan psikiatrik tetapi bukan merupakan satu-satunya atau tidak dapat berdiri sendiri untuk menyebabkan gangguan psikiatrik. ${ }^{11}$

Responden menurut suku sebagian besar Jawa $(40,6 \%)$ Hal ini dapat menjadi kajian berikutnya terkait dengan sosial budaya masyarakat Jawa yang dapat mempengaruhi perilaku sehat mereka.Di dalam penelitian sebelumnya dinyatakan bahwa budaya sangat mempengaruhi perilaku sehat masyarakatnya

\section{Analisis Bivariat}

Pada penelitian ini, fungsi kognitif dibagi dalam dua kategori berdasarkan pengukuran MoCA.Ditetapkan bahwa disebut nilai normal jika skor MoCA adalah $\geq 26$, jika dibawah 26 maka fungsi kognitif klien kurang. menunjukkan bahwa responden menurut skor fungsi kognitif yang dikelompokkan sebelum ECT sebagian besar kognitif kurang $(56,3 \%)$. Respons kognitif maladaptif termasuk ketidakmampuan untuk membuat keputusan, kerusakan memori dan penilaian, disorientasi, mispersepsi, penurunan rentang perhatian, dan kesulitan memberikan alasan yang logis. Respons kognitif ini dapat menyebabkan orang yang menderita berada pada status konfusi (bingung) - tidak mampu memahami dan belajar dari pengalaman dan tidak mampu menghubungkan peristiwa saat ini dengan masa lalu atau berinteraksi bermakna dengan orang lain. ${ }^{1}$

Pada responden menurut skor fungsi kognitif yang dikelompokkan sesudah ECT sebagian besar dengan kategori normal $(62,5 \%)$. Menunjukkan adanya peningkatan kognitif setelah klien diberikan ECT.Pada klien pasca ECT, umumnya mengalami konfusi dan defisit kognitif karena terapi tersebut, namun biasanya sementara, dan berakhir sekitar 30 menit. Pada penelitian Marangell, ${ }^{7}$ klien yang mendapatkan ECT melaporkan tidak ada masalah dengan memorinya, tetapi sedikit responden juga melaporkan bahwa memorinya tidak sebaik sebelum diberikan ECT. Hal ini sesuai dengan hasil penelitian ini, bahwa dari 32 responden terdapat 2 responden yang mengalami penurunan kognitif setelah diberikan ECT. Pada uji statistik didapatkan nilai $\mathrm{p}=0,019$ ( $\mathrm{p}$ $<$ 0,05), maka dapat disimpulkan ada perbedaan antara fungsi kognitif klien gangguan jiwa sebelum dan sesudah ECT atau ada pengaruh ECT terhadap fungsi kognitif klien gangguan jiwa.

\section{Kesimpulan}

Penelitian dilakukan di Ruang ECT Rumah Sakit Jiwa dr. Soeharto Heerdjan Jakarta pada bulan Januari-Maret 2017. Penelitian ini menggunakan desain penelitian quasi eksperimen pre-post intervensi tanpa kelompok kontrol dengan tujuan mengetahui gambaran mengenai pengaruh pemberian ECT terhadap peningkatan fungsi kognitif klien gangguan jiwa di Rumah Sakit Jiwa dr. Soeharto Heerdjan Jakarta. Sampel yang diperoleh dalam penelitian ini adalah 32 sampel. Adapun kesimpulan yang dapat ditarik dari penelitian ini adalah bahwa Karakteristik responden adalah sebagian besar diagnosis medisnya skizofrenia paranoid (F20.0), diagnosis keperawatan isolasi sosial, jenis kelamin laki-laki, berusia 20-30 tahun, tidak bekerja dan bersuku jawa, Fungsi kognitif yang dikelompokkan sebelum ECT sebagian besar kognitif kurang dan sesudah ECT dengan kategori normal, Ada pengaruh ECT terhadap fungsi kognitif klien gangguan jiwa.

\section{Saran}

Diharapkan rumah sakit dapatmenambah fasilitas ECT, meningkatkan kemampuan menggnakam penilaian kemampuan kognitif pada pasien gangguan jiwa serta peneliti selanjutnya dapat mengembangkan metode penilaian kemampuan kognitif pasien gangguan jiwa dengan eknik lain guna meningkatkan kesembuhan pasien gangguan jiwa. 


\section{Daftar Pustaka}

1. Stuart, Gail, W., \& Laraia, MT., Principle and Practice of Psychiatric Nursing. 8th ed. Philadelphia: Mosby Inc; 2017.

2. Towsend, Mary C. Buku Saku Diagnosa Keperawatan pada Perawatan Psikiatri. Edisi 3. Jakarta: penerbit Buku Kedokteran EGC; 2017.

3. Kaplan \& Saddock Sinopsis Psikiatri. Edisi 7. Jakarta: Bina Rupa Aksara. 2017.

4. Prita Daneswari. Terapi Kejut Listrik Sembuhkan Depresi Akut. Online http://www.mediaindonesia.com/mediahid upsehat/index.php/read/2010/08/19/3012/1 3/Terapi-Kejut-Listrik-Sembuhkan-

Depresi-Akut (Akses: 11 November 2017); 2018.

5. Bayless JD Pre- and PostElectroconvulsive Therapy Multidomain Cognitive Assessment in Psychotic Depression: Relationship to Premorbid Abilities and Symptom Improvement. Research. Department of Psychiatry, University of Iowa, Carver College of Medicine, Iowa City; 2017.

6. Notoatmodjo. Metodologi Penelitian Kesehatan. Jakarta : PT. Rineka Cipta; 2017.

7. Arikunto. Metodologi Penelitian Suatu Pendekatan Proposal. Jakarta: PT. Rineka Cipta; 2017.

8. Kaplan \& Saddock Sinopsis Psikiatri. Edisi 7. Jakarta: Bina Rupa Aksara; 2017.
9. DepKes RI. Pedoman Penggolongan dan Diagnosis Gangguan Jiwa di Indonesia III. Jakarta Direktorat Jenderal Pelayanan Medik Departemen Kesehatan RI. (12017).10. Keliat, BA., Proses Keperawatan Kesehatan Jiwa. Edisi 2. Jakarta: Penerbit Buku Kedokteran EGC; 2017.

11. Folstein MF, Folstein SE, McHugh PR "Mini-Mental State". A Practical Method for Grading the Cognitive State of Patients for the Clinician. Journal of psychiatric research; 2017.

12. 12. Keliat, B.A. Modul Model Praktek Keperawatan Profesional Jiwa. Jakarta: Fakultas Keperawatan Universitas Indonesia dan World Health Organization Indonesia; 2006.

13. Maramis, W.F. Catatan Ilmu Kedokteran Jiwa, Edisi 9. Surabaya: Airlangga University Press; 2005.

14. Keliat, B.A. Modul Model Praktek Keperawatan Profesional Jiwa. Jakarta: Fakultas Keperawatan Universitas Indonesia dan World Health Organization Indonesia; 2006.

15. Nurjanah, I. S.Kep. Pedoman Penanganan Pada Gangguan Jiwa. Yogyakarta: Memodia; 2009. 